\title{
Pentingnya Crowdfunding Dalam Era Digital
}

Crowdfunding ini merupakan suatu metode yang bertujuan untuk memahami bagaimana cara kita sebagai wirausaha dapat mengadopsi si crowdfunding ini kedalam humaniora digital dengan cara, menyelidiki penyimpangan misi, pembagian risiko, dan praktik SDM. Dalam menerapkan crowdfunding sendiri memerlukan beberapa strategi untuk mengadopsinya, diantaranya (1) mengadopsi platform crowdfunding itu sendiri untuk mendorong perusahaan sosial agar dapat membentuk kembali misi sosial dengan tindakan yang lebih responsif. (2) Crowdfunding sendiri dapat memungkinkan si wirausaha sosial untuk berbagi risiko dengan para pemangku kepentingan yang berfokus pada pengembangan dampak sosial digital human. (3) Crowdfunding juga dapat mendorong usaha sosial untuk mempekerjakan pekerja professional dengan pengaturan yang lebih fleksibel agar dapat menarik para investor.Terdapat banyak kota yang mengalami bentuk kolaborasi baru yang berdampak bagi warga dan pengusaha, maka dilakukannya analisis terhadap enam proyek yang menyoroti tantangan dan peluang crowdfunding sipil untuk penciptaan, pengembangan, dan peningkatan kota yang lebih inklusif ( Care \& Rizello, 2018 ). Crowdfunding juga dapat digunakan dalam tata kelola kota yang menghargai kewirausahaan sosial serta membentuk ekologi yang khas dan beragam ( Langley \& Vradis, 2020 ). 


\section{Reference}

Pratono, A.H. et al (2020) Crowdfunding in digital humanities: some evidence from Indonesian social enterprises, Aslib Journal of Information Management 72(2), 287-303.

Langley P, Vradis A ( 2020 ) Crowdfunding cities: Social entrepreneuship, speculation, and solidarity in Berlin, Geoforum ( 115 ), 11-20

Care S, Rizzelo A ( 2018 ) Crowdfunding for the development of smart cities, Business

Horizons 61(4), 501-509 